\title{
Application of respiratory metagenomics for COVID-19 patients on the intensive care unit to inform appropriate initial antimicrobial treatment and rapid detection of nosocomial transmission
}

Themoula Charalampous ${ }^{1 *}$, Adela Alcolea-Medina ${ }^{1,2 *}$, Luke B. Snell ${ }^{1,3^{*}}$, Tom G.S Williams ${ }^{3}$, Rahul Batra ${ }^{1,3}$, Luigi Camporota ${ }^{4}$, Christopher I.S. Meadows ${ }^{4}$, Duncan Wyncoll ${ }^{4}$, Nicholas A. Barrett ${ }^{4}$, Carolyn J. Hemsley ${ }^{3}$, Lisa Bryan², William Newsholme ${ }^{3}$, Sara E. Boyd ${ }^{3}$, Anna Green ${ }^{5}$, Ula Mahadeva ${ }^{5}$, Amita Patel ${ }^{1,3}$, Penelope R. Cliff ${ }^{2}$, Andrew J. Page ${ }^{6}$, Justin O'Grady ${ }^{6 \wedge}$ and Jonathan D. Edgeworth ${ }^{1,2,3 \wedge}$.

${ }^{1}$ Centre for Clinical Infection and Diagnostics Research, Department of Infectious Diseases, School of Immunology and Microbial Sciences, Kings College London, London

${ }^{2}$ Infection Sciences, St Thomas' Hospital, Viapath, London

${ }^{3}$ Department of Infectious Diseases, Guy's and St Thomas' Hospital NHS Foundation Trust, London

${ }^{4}$ Critical Care Directorate, Guy's and St Thomas' Hospital NHS Foundation Trust, London

${ }^{5}$ Department of Cellular Pathology, Guy's and St Thomas' NHS Foundation Trust, London, UK.

${ }^{6}$ Quadram Institute Bioscience, Norwich Research Park, Norwich, UK

*These authors contributed equally

$\wedge$ Senior and corresponding authors 
medRxiv preprint doi: https://doi.org/10.1101/2020.11.26.20229989; this version posted December 3, 2020. The copyright holder for this preprint (which was not certified by peer review) is the author/funder, who has granted medRxiv a license to display the preprint in It is made available under a CC-BY-NC-ND 4.0 International license .

\section{Abstract}

Background. Clinical metagenomics $(\mathrm{CMg})$ is being evaluated for translation from a research tool into routine diagnostic service, but its potential to significantly improve management of acutely unwell patients has not been demonstrated. The SARS-CoV-2 pandemic provides impetus to determine that benefit given increased risk of secondary infection and nosocomial transmission by multi-drug resistant (MDR) pathogens linked with expansion of critical care capacity.

Methods. Prospective evaluation of CMg using nanopore sequencing was performed on 43 respiratory samples over 14 weeks from a cohort of 274 intubated patients across seven COVID-19 intensive care units.

Results. Bacteria or fungi were cultured from 200 (73\%) patients, with a predominance of Klebsiella spp. (31\%) and C. striatum (7\%) amongst other common respiratory pathogens. An 8 hour CMg workflow was $93 \%$ sensitive and $81 \%$ specific for bacterial identification compared to culture, and reported presence or absence of $\beta$-lactam resistance genes carried by Enterobacterales that would modify initial guideline-recommended antibiotics in every case. CMg was also 100\% concordant with quantitative PCR for detecting Aspergillus fumigatus (4 positive and 39 negative samples). Single nucleotide polymorphism (SNP)typing using 24 hour sequence data identified an MDR-K. pneumoniae ST307 outbreak involving 4 patients and an MDR-C. striatum outbreak potentially involving 14 patients across three ICUs.

Conclusion. CMg testing for ICU patients provides same-day pathogen detection and antibiotic resistance prediction that significantly improves initial treatment of nosocomial pneumonia and rapidly detects unsuspected outbreaks of MDR-pathogens. 
medRxiv preprint doi: https://doi.org/10.1101/2020.11.26.20229989; this version posted December 3, 2020. The copyright holder for this preprint (which was not certified by peer review) is the author/funder, who has granted medRxiv a license to display the preprint in It is made available under a CC-BY-NC-ND 4.0 International license .

\section{Introduction}

The intensive care unit (ICU) is a dynamic environment with frequent staff-contact for invasive monitoring, interventions and personal care that together introduce risk of secondary or nosocomial infection (1). Invasive ventilation can introduce organisms into the lungs causing ventilator-acquired pneumonia (VAP) which carries high attributable mortality and drives up to $70 \%$ of antimicrobial prescribing (2). Typically, patients with suspected VAP receive guideline-directed empiric antibiotics until culture results return, typically $2-4$ days later, although therapy isn't always adjusted when results are returned $(3,4)$. Invasive pulmonary aspergillosis (IPA) is also increasingly recognised on ICU particularly with severe influenza $(5,6)$ and after host immunosuppression, but culture lacks sensitivity, biomarker tests have low specificity and long turnaround times (7) and gold-standard histopathology is rarely used (8).

SARS-CoV-2 has put considerable strain on ICUs, due to expansion of bed capacity, which has potential to increase nosocomial infection and antimicrobial resistance (AMR). High prevalence of Gram-negative bacteria (GNB) particularly Klebsiella spp. have been reported (9-11) and there are reports of secondary IPA (12-15). COVID-19 patients also receive steroid therapy, which could exacerbate bacterial or fungal infection $(16,17)$. The COVID-19 pandemic therefore re-enforces the need for rapid comprehensive diagnostics to improve empiric therapy and help prevent emergence and transmission of MDR-organisms.

Clinical metagenomic $(\mathrm{CMg})$ using nanopore technology has potential to meet these needs due to its unbiased pan-microbial coverage $(18,19)$ and ability to provide real-time data acquisition and analysis (20). It has been evaluated for respiratory, urinary tract and prosthetic joint infections (20-23), however, the full clinical potential required for laboratories and clinical teams to change their long-standing practice has not been demonstrated. We therefore prospectively assessed whether CMg testing of respiratory samples from COVID19 patients with suspected secondary bacterial or fungal pneumonia, could significantly 
medRxiv preprint doi: https://doi.org/10.1101/2020.11.26.20229989; this version posted December 3, 2020. The copyright holder for this preprint (which was not certified by peer review) is the author/funder, who has granted medRxiv a license to display the preprint in It is made available under a CC-BY-NC-ND 4.0 International license .

improve their initial antimicrobial treatment and detect outbreaks affecting a large COVID-19 patient cohort across 7 ICUs.

\section{Results}

\section{Clinical and microbiological characteristics of COVID-19 patients}

274 consecutive invasively-ventilated COVID-19 patients were admitted between March $20^{\text {th }}$ and June $24^{\text {th }} 2020$ (Table 1), including 103 inter-hospital transfers for specialist care and assessment for extracorporeal membrane oxygenation (ECMO). Median age was 56 and $71 \%$ were male. Median length of hospital-stay was 19 days (Interquartile range (IQR) 1237) and 196 patients (71\%) were discharged alive from hospital. 763 respiratory samples were processed from 225 (82\%) patients, with organisms isolated from at least one sample in $77 \%$ of patients. The main GNB were Klebsiella spp. (31\%) Citrobacter spp. (23\%), E. coli (7\%), and P. aeruginosa (7\%). The main Gram-positive bacteria were S. aureus (10\%), Enterococcus spp. (7\%) and C. striatum (7\%). C. albicans, other Candida spp. and Aspergillus spp. were cultured from $28 \%, 8 \%$ and $2 \%$ of patients respectively. CMg was performed on 43 samples from 34 patients selected because of strong clinical suspicion of secondary infection. All respiratory pathogens cultured from the whole cohort were represented in CMg samples including 5 of the 6 patients from which Aspergillus spp. was isolated.

There were 79 clinically-significant blood stream infections (BSIs) of which 36 were coagulase-negative Staphylococci. Klebsiella spp. were the second most frequent $(n=19)$ representing $57 \%$ of all GNB-BSIs, comprising $12 \mathrm{~K}$. pneumoniae, $5 \mathrm{~K}$. aerogenes, $1 \mathrm{~K}$. oxytoca and 1 K. variicola (Supplementary Table 1). Nine K. pneumoniae BSIs had acquired $\beta$-lactam resistance and, overall, 15 (79\%) BSIs caused by Klebsiella spp and 70/94 (74\%) patients with respiratory Klebsiella spp. isolates had phenotypic resistance to first-line empiric antibiotic treatment for nosocomial pneumonia (piperacillin-tazobactam). There were few BSIs with other organisms: E. coli $(\mathrm{n}=5), P$. aeruginosa $(\mathrm{n}=4)$ and $S$. aureus $(\mathrm{n}=2)$. 
medRxiv preprint doi: https://doi.org/10.1101/2020.11.26.20229989; this version posted December 3, 2020. The copyright holder for this

preprint (which was not certified by peer review) is the author/funder, who has granted medRxiv a license to display the preprint in

It is made available under a CC-BY-NC-ND 4.0 International license .

\section{Performance of $\mathrm{CMg}$ compared with routine culture for pathogen detection}

Potential respiratory pathogens were cultured from $27 / 43(63 \%)$ samples tested by CMg and 16 samples (14 patients) were reported either as no growth or not clinically significant. CMg identified 25/27 culture-reported pathogens (93\% sensitive; 95\% Cl, 76-99\%) (Table 2). It did not report scanty $K$. aerogenes in two polymicrobial samples (S44 and S45) that were present below pre-defined thresholds (supplementary Table 2A). CMg reported 3 additional pathogens in 3 culture negative samples: 1 A. fumigatus and 2 S. aureus (specificity $81 \%$ $(95 \% \mathrm{Cl}, 54-96 \%)$. The additional $A$. fumigatus was from a patient growing $A$. fumigatus in other respiratory samples (S55). One S. aureus false positive sample contained high levels of $S$. epidermidis ( $>15,000$ reads) and a proportion of the sequence reads can be incorrectly identified as S. aureus (S16). The other additional S. aureus was in a sample (S41) containing multiple commensals, so may have been missed by culture-plate reading (suppl. Table 6).

CMg also identified 9 additional pathogens in 7 culture-positive samples (Table 2). 4 were identified by culture in other respiratory samples from those patients (K. oxytoca (S8), $K$. pneumoniae (S37), C. striatum (S52) and C. koseri (S61). All these additional CMg reported bacteria were considered true positives and clinically reportable.

\section{Impact of resistance gene detection on guideline-directed empiric antibiotic selection}

Two-hour CMg sequencing data was analysed from 21 of 27 culture-positive samples where presence of acquired resistance could impact on guideline-directed treatment (Table 3).

There was genotypic and phenotypic concordance in all but one sample. Extended spectrum $\beta$-lactamase (ESBL) genes were detected in 4 samples containing Enterobacterales with phenotypic resistance, blatem genes in S31, S49 and S59, blashv and blactX-m in S31 and S59 and blasHv in S63. No $\beta$-lactamase resistance genes were found in 9 samples containing 
medRxiv preprint doi: https://doi.org/10.1101/2020.11.26.20229989; this version posted December 3, 2020. The copyright holder for this preprint (which was not certified by peer review) is the author/funder, who has granted medRxiv a license to display the preprint in It is made available under a CC-BY-NC-ND 4.0 International license .

10 susceptible Enterobacterales (Supplementary Table 3), but blaтем and blasнv genes were detected in a sample with K. pneumoniae having no reported phenotypic acquired resistance (S34). Resistance phenotypes could not be genotypically predicted in two samples with light bacterial-growth of $A$. baumanni (S35) and K. aerogenes (S62) due to low read count. No carbapenemases were detected in any sample and no $\mathrm{SCC}_{\mathrm{mec}}$ elements in the two samples growing S. aureus. Genes conferring resistance against non-guideline recommended antibiotics were detected, all consistent with reported phenotypes (Table 3).

CMg data would have informed meropenem therapy in 11/21 cases, based on speciation in $7(33 \%)$ and acquired resistance-genotype in 4 (19\%). CMg data would have guided the use of co-amoxiclav therapy in 9 based on speciation combined with absence of $\beta$-lactamases (43\%). In 1/21 (5\%) cases CMg directed antibiotic choice was not consistent with culture from S34 where identification of an ESBL was not phenotypically confirmed by culture.

\section{Comparison of methods for diagnosis of IPA}

763 respiratory samples from 225 patients were cultured to identify $A$. fumigatus, and galactomannan (GM) antigen detection tests were requested on bronchoalveolar lavage and serum samples from $51(19 \%)$ and $74(27 \%)$ patients, respectively. Nine patients had at least one mycology result consistent with IPA (Table 4). Four of five culture positive patients met original AspICU criteria (24) and all met modified AspICU criteria that do not require predisposing host factors (25). Four persistently culture negative patients had positive BALGM and met modified AspICU criteria (26); none of these had Aspergillus detected by CMg and qPCR.

Two-hour CMg sequence data identified $A$. fumigatus reads in all of the 3 culture-positive samples that were tested by CMg (S8 [77 reads], S28 [2649 reads] and S56 [79 reads]) and a sample from a patient with $A$. fumigatus in other diagnostic samples (S55 [16 reads]) - see Supplementary table 2A. Probe-based qPCR (27) was 100\% concordant with CMg (Table 4). One sample from a patient (S18) growing $A$. fumigatus in other samples was negative by 
medRxiv preprint doi: https://doi.org/10.1101/2020.11.26.20229989; this version posted December 3, 2020. The copyright holder for this preprint (which was not certified by peer review) is the author/funder, who has granted medRxiv a license to display the preprint in It is made available under a CC-BY-NC-ND 4.0 International license .

culture, qPCR and metagenomic sequencing. There was discordance between GM tests and culture, and between BAL-GM and serum-GM. Four culture positive patients had at least one BAL-GM performed, with three patients having at least one positive BAL-GM result, and 2 of 3 culture-positive patients who were tested with serum-GM had a positive result.

Post-mortem histology from patient 563 with $A$. fumigatus identified by culture and $\mathrm{CMg}$ revealed a single $1 \mathrm{~cm} \times 1 \mathrm{~cm}$ patch of IPA and no A. fumigatus in other organs. There was extensive diffuse alveolar damage and IPA was not reported to have contributed to death (Supplementary Fig.1).

\section{CMg detection of hospital transmission}

Higher than anticipated prevalence of Klebsiella spp. and C. striatum raised the possibility of patient to patient transmission that was investigated by analysis of 24 hour CMg sequencing data.

\section{Klebsiella pneumoniae}

Consensus sequence was generated using K. pneumoniae reads from 8 samples (8 patients). Different sequence-types (ST) were determined in four samples (S11, S34, S59 and S63). No ST could be determined for the remaining three samples (S10, S31 and S61), and S49 was excluded from analysis due to 3\% genome coverage (Supplementary Table 5C). Comparison of high quality allele calls and pairwise comparison of bases from all samples showed S31 was similar to S59 (ST307) with 55 SNP-based differences from $4,892,921$ bases $(99.999 \%$ identical). This indicates a recent evolutionary history with differences likely due to nanopore sequencing errors. All other samples differed by tens of thousands of SNPs (Supplementary Table 5B).

Two additional patients (301 and 968) had a K. pneumoniae-BSI with identical broad resistance phenotype as CMg samples S31 and S59 (patient 1054 and 740 respectively). Pairwise comparison of SNP differences across all 4 genomes showed they were virtually 
medRxiv preprint doi: https://doi.org/10.1101/2020.11.26.20229989; this version posted December 3, 2020. The copyright holder for this preprint (which was not certified by peer review) is the author/funder, who has granted medRxiv a license to display the preprint in It is made available under a CC-BY-NC-ND 4.0 International license .

identical with 5-55 SNP differences (see supplementary Table 5D). Epidemiological analysis found all 4 patients with this K. pneumoniae ST307 clone had overlapping stays on one ICU implicating an unsuspected outbreak (Fig. 1A).

\section{Klebsiella aerogenes}

Consensus sequence generated using $K$. aerogenes reads from S1, S52 and S62 identified 49,007 SNPs from 4,647,134 bases in S1 and S52, (S62 was excluded due to 1.5\% genome coverage). S1 and S52 were only $98.94 \%$ identical and differed in the allele leuS (14 vs 29) indicating they were not part of an outbreak.

\section{Corynebacterium striatum}

Analysis of consensus sequence using $C$. striatum reads from $5 / 6$ samples (S45, S52,S54, S59 and S63) from 4 patients showed 71,339 of 2,758,551 bases present in all consensus sequences with a maximum 4 SNPs - (S62 (patient 749) was excluded due to $3.2 \%$ genome coverage). Reviewing all positions where there was a base in all samples, the maximum distance was 157 SNPs from 1,486,708 bases (99.99\% identity) implying they were part of an outbreak (supplementary Table 5A). Epidemiological analysis of all 18 patients with $C$. striatum identified overlapping ward-stays for 14/18 patients across three ICUs, with genome sequence data implicating an extensive outbreak associated with patient movement between ICUs (Fig.1B).

\section{Discussion}

This study illustrates the significant challenge facing COVID-19 ICUs with high rates of secondary infection and antimicrobial resistance in a setting that had prior sustained successful antimicrobial stewardship and infection control programmes $(28,29)$. There were particularly high rates of Klebsiella spp. infection with of respiratory $74 \%$ and $79 \%$ of $\mathrm{BSI}$ Klebsiella isolates having intrinsic or acquired resistance to first-line antibiotics (piperacillintazobactam). We show how a single respiratory $\mathrm{CMg}$ test provides pathogen identification 
medRxiv preprint doi: https://doi.org/10.1101/2020.11.26.20229989; this version posted December 3, 2020. The copyright holder for this preprint (which was not certified by peer review) is the author/funder, who has granted medRxiv a license to display the preprint in It is made available under a CC-BY-NC-ND 4.0 International license .

and accurate AMR-prediction within an eight-hour laboratory workflow, and SNP-typing data the following day. This demonstrates for laboratories, intensivists, pharmacists and infection control teams the full benefit of $\mathrm{CMg}$, with particular relevance to ICU settings that have unpredictable epidemiology and high levels of AMR such as, is being seen with COVID-19. Demonstrating these benefits is necessary to support the introduction of $\mathrm{CMg}$ into predominantly culture-based microbiology laboratories, and for the multidisciplinary team to change their clinical practice to accommodate rapid comprehensive information on ICUpathogens. Previous studies have given examples of how CMg can diagnose respiratory infection $(20,23,30-35)$, predict $\operatorname{AMR}(18,36,37)$ and provide genotyping data (37-39), but here for the first time, all these outputs are combined in a single test demonstrating the impact CMg would have when applied in a challenging real-world setting.

CMg was $93 \%$ sensitive and $81 \%$ specific for bacterial and fungal detection, consistent with previous estimates $(20,40-41)$. Discrepancies were mostly within polymicrobial samples with scanty growth of undetected pathogens (2 false negatives), which makes their clinical significance questionable, or where culture potentially missed the pathogen ( 3 false positives). Culture is a recognised imperfect gold standard, meaning specificity is likely to have been underestimated. These discordant results are not of major concern, as $\mathrm{CMg}$ thresholds can be refined further, allowing future translation of CMg into service evaluation.

We assessed the impact of 2-hour CMg AMR results against the updated ICU antimicrobial treatment guideline for COVID-19 patients that recommended piperacillin-tazobactam as first-line therapy, which is common practice in the UK $(43,44)$. CMg accurately detected acquired $\beta$-lactam genes conferring phenotypic resistance to recommended antibiotics for the main respiratory pathogens, particularly Enterobacteriales. Speciation or ESBL-detection would inform meropenem therapy in $33 \%$ and $19 \%$ of cases respectively rather than piperacillin-tazobactam. This is significant given meropenem improves survival compared with piperacillin-tazobactam for patients with ESBL-Enterobacterales infection (42). Conversely in $43 \%$ of cases combined speciation and absence of detected $\beta$-lactamases 
medRxiv preprint doi: https://doi.org/10.1101/2020.11.26.20229989; this version posted December 3, 2020. The copyright holder for this preprint (which was not certified by peer review) is the author/funder, who has granted medRxiv a license to display the preprint in It is made available under a CC-BY-NC-ND 4.0 International license .

would inform co-amoxiclav therapy, aiding antimicrobial stewardship. Thus CMg-results for the 21 samples would not inform piperacillin-tazobactam use in any case. We did not demonstrate ability to detect MRSA or carbapenemase-producing Enterobacterales as they were absent from our cohort, however this is expected to be feasible using the same methods. CMg also detected an ESBL in one K. pneumoniae sample that was not phenotypically confirmed; whilst this lead to unnecessary escalation to meropenem the antibiotic suggested by $\mathrm{CMg}$ is still effective against the organism. Predicting AMR in $P$. aeruginosa and some other non-fermentors using CMg has not been demonstrated here, with further work required to delineate genotypic correlates with phenotypic resistance to allow same-day resistance prediction in these organisms. Nevertheless, this study illustrates the huge impact routine CMg could have on treating ICU infections, particularly where there are high or changing rates of resistance.

$\mathrm{CMg}$ also demonstrated potential to help with diagnosing IPA. It detected all culture positive samples and was $100 \%$ concordant with targeted qPCR, whereas half the patients with a positive GM result were not confirmed by the other three testing methodologies. Diagnosing secondary-IPA is difficult with severe viral infections $(5,45,46)$ and particularly COVID-19 patients, who commonly fulfil all radiological, clinical and host diagnostic criteria (47)(24). IPA in COVID-19 patients, was uncommon in our study (about $2 \%$ ) as in other London centres $(26,48)$. Albeit, the single small focus of IPA in only one post-mortem reported here and elsewhere (49-51), suggests COVID-19-related IPA may not be as clinically-significant as with influenza. Thus taken together, $\mathrm{CMg}$ shows potential as a rapid diagnostic for IPA, although further studies in other settings are required (52).

Finally, 24 hour CMg data identified outbreaks that help explain the epidemiology of secondary infection on COVID-19 ICUs. It identified an MDR-K. pneumoniae ST307 outbreak which is a particular concern given its resistance profile and extensive international spread $(54,55)$. Hospital transmission may therefore help explain the high prevalence of Klebsiella spp. reported here and potentially elsewhere $(44,53)$. CMg also identified an 
medRxiv preprint doi: https://doi.org/10.1101/2020.11.26.20229989; this version posted December 3, 2020. The copyright holder for this preprint (which was not certified by peer review) is the author/funder, who has granted medRxiv a license to display the preprint in It is made available under a CC-BY-NC-ND 4.0 International license .

MDR-C. striatum outbreak potentially involving 14 patients. The clinical significance of detecting $C$. striatum in respiratory specimens is unclear although MDR-C. striatum outbreaks (as noted here) are also reported elsewhere (56-58). These findings highlight again the benefit of unbiased pathogen detection using CMg in revealing hidden outbreaks.

Further work is required to implement $\mathrm{CMg}$ into routine service, particularly automation of sample preparation to accommodate routine testing. Resistance prediction and SNP typing was also not possible in two samples due to low pathogen quantity present in samples. Further quality controls are also required for laboratory accreditation, and development of the bioinformatics tools to clinical standard for real-time analysis and generation of clinical reports. Finally, intensivists would need to change prescribing practice in response to $\mathrm{CMg}$ results, which may be challenging when advised to use narrower-spectrum antibiotics or withhold antibiotics when pathogens are not detected.

In summary, this study demonstrates how CMg testing identifies bacterial and fungal infections, AMR and hospital transmission events in a single rapid test. CMg could significantly improve the management of infection and transmission on ICU, with immediate potential benefit for COVID-19 patient cohorts that have heightened risk of secondary infection with MDR-pathogens (59). Early targeted therapy presents a clear opportunity to improve patient outcomes and antimicrobial stewardship. Further clinical evaluation of an ICU CMg service is our priority for the next wave of the COVID-19 pandemic.

\section{Methods}

\section{Clinical setting and data collection}

Clinical, microbiological and ward location data were collected by the primary care team from all patients with a documented SARS-CoV-2 RT-PCR positive test admitted to the 3 preexisting and 4 newly-opened COVID-19 ICUs. 2 pre-existing ICUs doubled bed-capacity and all healthcare staff used additional personal protective equipment according to PHE guidelines. Updated ICU empiric antimicrobial guidelines recommended 3 days co-amoxiclav 
medRxiv preprint doi: https://doi.org/10.1101/2020.11.26.20229989; this version posted December 3, 2020. The copyright holder for this preprint (which was not certified by peer review) is the author/funder, who has granted medRxiv a license to display the preprint in It is made available under a CC-BY-NC-ND 4.0 International license .

on admission, piperacillin-tazobactam for first suspected acquired respiratory infection and meropenem for subsequent infections or where resistance was suspected.

\section{Sample selection and analysis}

Aliquots of surplus clinical respiratory samples, submitted by intensivists each day and selected by the infectious diseases consult team based on the patient having a high probability of secondary infection, were retrieved after routine processing. Samples were anonymised prior to submission to the research team. The clinical care team collected relevant clinical and laboratory data to create an anonymised dataset given to the research team who had no access to patient identifiable data at any time. The clinical team was not aware of the CMg results while caring for the patients. The full process for sample collection, nanopore sequencing, data linkage and anonymization was approved by a research ethical committee (North West Preston REC: reference 18/NW/0584).

\section{Routine microbiological processes}

Respiratory samples were processed according to standard laboratory practice in an ISO15189 accredited laboratory (supplementary methods). Galactomannan (GM) antigen detection was performed by Mycology Reference Laboratory, Bristol using the Platelia ${ }^{\mathrm{TM}}$ Aspergillus Antigen kit (BIO-RAD - 62794). Definitions of respiratory pathogens were based on standard criteria as previously done by other studies $(20,40)$ - non-respiratory pathogens identified are listed in Supplementary Table 6.

\section{A. fumigatus qPCR assay}

Probe-based qPCR assay was performed to amplify and detect $A$. fumigatus DNA using the QuantStudio 7 Flex (Applied Biosystems). Reagents and reactions were set up as previously described in (20) and (27) respectively. 
medRxiv preprint doi: https://doi.org/10.1101/2020.11.26.20229989; this version posted December 3, 2020. The copyright holder for this preprint (which was not certified by peer review) is the author/funder, who has granted medRxiv a license to display the preprint in It is made available under a CC-BY-NC-ND 4.0 International license .

\section{Nanopore metagenomic sequencing}

Host DNA depletion, microbial DNA extraction and sequencing was performed using previously published methods (20) with minor modifications presented in detail in supplementary methods. Samples were batched for CMg-sequencing (6 samples per run). Library preparation was performed using the Rapid PCR Barcoding Kit (ONT) with a 6 min extension time as previously described (20). Library was loaded onto nanopore flow cells (R9.4.1) with sequencing performed on the GridION platform. ONT MinKNOW software (version 3.6.5) acquired raw sequence data with live basecalling by ONT Guppy (version 3.2.10). Sequencing was run for 24 hours with the first 2 hour data used for pathogen identification by WIMP analysis. Human reads were discarded by alignment with genome reference (GCA_000001405.15, assembly GRCh38.p13 version) and non-human reads were exported and used for pathogen identification and AMR gene detection as previously described (20).

\section{Pathogen identification and acquired resistance gene prediction}

EPI2ME Antimicrobial Resistance pipeline (ONT, version v2020.2.10-3247478) was used for bacterial and fungal pathogen identification as previously described (20). Potential bacterial pathogen(s) were reported if $\geq 1 \%$ of total microbial reads and centrifuge score $\geq 2504$. Aspergillus spp. were reported if $\geq 10$ reads and a centrifuge score $\geq 2504$. To remove possible contamination and barcode cross-talk, $0.1 \%$ of total pathogenic reads of any pathogens with $>10,000$ classified cumulative microbial reads were removed from all channels. Any remaining pathogens in the negative control ( $>5$ classified reads) were considered contaminants and were removed from all the channels.

Acquired resistance genes were detected from 2 hours of sequencing with Scagaire (https://github.com/quadram-institute-bioscience/scagaire) using Abricate analysis as an input (https://github.com/tseemann/abricate). Clinically-relevant gene alignments with $>90 \%$ coverage were removed and only resistance genes with $>1$ gene alignment were reported to 
medRxiv preprint doi: https://doi.org/10.1101/2020.11.26.20229989; this version posted December 3, 2020. The copyright holder for this preprint (which was not certified by peer review) is the author/funder, who has granted medRxiv a license to display the preprint in It is made available under a CC-BY-NC-ND 4.0 International license .

remove possible bioinformatics errors (suppl. Table 3). Analysis for acquired genotypic resistance was performed for $\beta$-lactamases that impact on guideline-directed antibiotic choices (supplementary methods).

\section{Nanopore sequencing of $K$. pneumoniae BSI-isolates}

DNA was extracted from stored K. pneumoniae BSI isolates by bead beating for $4 \mathrm{~m} / \mathrm{s}$ for 40s seconds using Matrix E beads (MP Biomedicals ${ }^{\mathrm{TM}}$ ) on MP Biomedicals ${ }^{\mathrm{TM}}$ FastPrep-24 ${ }^{\mathrm{TM}}$ $5 G$ Instrument (MP Biomedicals ${ }^{\mathrm{TM}}$ ) - see supplementary methods. Extracted DNA was washed with 0.5X of Agencourt AMPure XP beads (Beckman Coulter-A63881) and prepared for nanopore sequencing using the Native barcoding genomic DNA (ONT - EXP-NBD114 and SQK-LSK109 kits). Isolates were sequenced on a GridION for 48 hours, following manufacturer's instructions.

\section{Klebsiella spp. and C. striatum SNP analysis}

Representative complete reference genomes for each species were downloaded from RefSeq to generate consensus sequences (63) for K. pneumoniae reads from 8 patients (8 samples), C. striatum reads in 6 samples (4 patients) and K. aerogenes reads from 4 samples (3 patients) (supplementary methods). SNP-sites (v2.5.1) (66) was used to identify SNPs between each sample and SNP distances were calculated using SNP-dists (v0.7.0) (https://github.com/tseemann/snp-dists). Multi-locus sequence typing was performed using mlst (v2.19.0) (https://github.com/tseemann/mlst).

\section{Data availability}

Sequence data presented in this study can be accessed on the European Nucleotide Archive (ENA) - study accession number PRJEB41184.

\section{Acknowledgments}

This research was funded/supported by the National Institute for Health Research (NIHR) Biomedical Research Centre based at Guy's and St Thomas' National Health Service (NHS) 
medRxiv preprint doi: https://doi.org/10.1101/2020.11.26.20229989; this version posted December 3, 2020. The copyright holder for this preprint (which was not certified by peer review) is the author/funder, who has granted medRxiv a license to display the preprint in It is made available under a CC-BY-NC-ND 4.0 International license .

Foundation Trust and King's College London, the programme of Infection and Immunity (RJ112/N027) J.D.E and T.C. J.O.G was supported by the Biotechnology and Biological Sciences Research Council (BBSRC) Institute Strategic Programme Microbes in the Food Chain BB/R012504/1 and its constituent projects BBS/E/F/000PR10348, BBS/E/F/000PR10349, BBS/E/F/000PR10351, and BBS/E/F/000PR10352 and Innovate UKChina AMR grant TS/S00887X/1. A.J.P. was supported by the Quadram Institute Bioscience BBSRC funded Core Capability Grant (project number BB/CCG1860/1). We thank Dr. Vivek Sekhwat (Speciality Trainee, Histopathology) and Ms Lara Iredale (Senior Anatomical Pathology Technologist) for contributing to the supplementary histopathology Figure 1.

\section{Author contributions}

The study was designed by J.D.E, J.O.G., and T.C. Clinical data were collected by J.D.E, L.B.S, T.G.S.M., C.I.S.M., C.M., A.G., U.M., Laboratory work and data analysis were performed by T.C., A.AM., L.B.S and A.J.P. Clinical samples were collected and analysed by A.AM. and L.B. S.G. and D.R. All authors contributed to the write-up and review of the manuscript.

\section{Figure Legends}

Figure 1. Identification of MDR K. pneumoniae and $C$. striatum outbreaks across the ICU network based on combined epidemiological and CMg analysis.

Overlapping ward stays for patients involved in putative outbreaks of A) MDR $K$. pneumoniae and B) C. striatum. Each row represents a unique patient. Patients are ordered by ward of first positive (ascending) and then by patient ID (ascending). Horizontal axis shows ward stays from April 1st to Jun 20th. Non ITU wards are colored in grey. ITU wards are labelled 1-10 represented by a unique colour. Periods outside the hospital are represented in white. MDR-K. pneumoniae or $C$. striatum positive and negative respiratory samples are marked as (+) or (-) respectively. Patients with a CMg-aligned sequence have 
medRxiv preprint doi: https://doi.org/10.1101/2020.11.26.20229989; this version posted December 3, 2020. The copyright holder for this preprint (which was not certified by peer review) is the author/funder, who has granted medRxiv a license to display the preprint in It is made available under a CC-BY-NC-ND 4.0 International license .

an S number (respiratory sample) or KP number (blood culture) adjacent to their identification number on the left of each bar.

Figure 1A continued: CMg was performed on MDR-K. pneumoniae in respiratory samples from patients 1054 and 301 and blood stream infection isolates on patients 301 and 968 retrieved from the routine diagnostic laboratory (timepoint marked as B). Possible chain of transmission is from top to bottom. No sequenced patient could link 968 to 1517 or 618 to 740 and so were assumed to be due to cryptic transmission via other non-sequenced patients.

Figure 1B continued: $\mathrm{CMg}$ was performed on $C$. striatum in respiratory samples from patient $618,677,740$ and 749 . All other patients were linked by epidemiology only

\section{Tables}

Table 1. Clinical characteristics and results of routine microbiological tests performed on intubated COVID-19 patients across 7 linked dedicated COVID-19 intensive care units on Guy's and St Thomas' hospital sites.

Table 2. Comparison of pathogens reported by routine culture with metagenomics sequencing in respiratory samples.

Table 3. Comparison of CMg identified acquired genotypic resistance with phenotypic culture results and the impact on guideline-recommended antibiotic treatment

Table 4. Mycological tests and clinical characteristics of patients with at least one result suggestive of invasive pulmonary aspergillosis. 
medRxiv preprint doi: https://doi.org/10.1101/2020.11.26.20229989; this version posted December 3, 2020. The copyright holder for this preprint (which was not certified by peer review) is the author/funder, who has granted medRxiv a license to display the preprint in It is made available under a perpetuity.

perpetuity.

Table 1. Clinical characteristics and results of routine microbiological tests performed on intubated COVID-19 patients across 7 linked dedicated COVID-19 intensive care units on Guy's and St Thomas' hospital sites

\begin{tabular}{|c|c|c|c|}
\hline & $\begin{array}{c}\text { All } \\
(n=274)\end{array}$ & $\begin{array}{l}\text { Metagenomics } \\
\text { group }^{\mathrm{a}} \\
(\mathrm{n}=34)\end{array}$ & $\begin{array}{c}\text { Non-metagenomics } \\
\text { group } \\
(n=240)\end{array}$ \\
\hline Median age (IQR) & $56(45-63)$ & $52(41-58)$ & $56(46-63)$ \\
\hline Sex - Male & $195(71 \%)$ & $23(70 \%)$ & $172(72 \%)$ \\
\hline \multicolumn{4}{|l|}{ Ethnicity } \\
\hline White & $98(36 \%)$ & $15(45 \%)$ & $83(35 \%)$ \\
\hline Black and Minority Ethnicities & $110(40 \%)$ & $15(45 \%)$ & $95(41 \%)$ \\
\hline Not known & $65(24 \%)$ & $3(9 \%)$ & $62(26 \%)$ \\
\hline Mortality & $78(29 \%)$ & $8(24 \%)$ & $71(30 \%)$ \\
\hline Length of stay (IQR) & 19 days $(12-37)$ & 32 days $(24-47)$ & 17 days $(11-32)$ \\
\hline \multicolumn{4}{|l|}{ Respiratory Cultures in ITUb } \\
\hline Median samples per patient (IQR) & $2(1-4)$ & $4.5(3-6)$ & $2(1-3)$ \\
\hline Total number of samples / Patients tested & $763 / 225$ & $183 / 33$ & $580 / 192$ \\
\hline \multicolumn{4}{|c|}{$\begin{array}{l}\text { Organisms from respiratory culture whilst in ICU (Number of individuals who ever had the following organisms } \\
\text { in any sample) }\end{array}$} \\
\hline Klebsiella spp+. & $86(31 \%)$ & $19(56 \%)$ & $67(28 \%)$ \\
\hline Staphylococcus aureus & $27(10 \%)$ & $3(9 \%)$ & $24(10 \%)$ \\
\hline Citrobacter spp. & $23(8 \%)$ & $6(18 \%)$ & $17(7 \%)$ \\
\hline Escherichia coli & $19(7 \%)$ & $4(12 \%)$ & $15(6 \%)$ \\
\hline Pseudomonas spp. & $19(7 \%)$ & $2(6 \%)$ & $17(7 \%)$ \\
\hline Corynebacterium striatum & $18(7 \%)$ & $8(24 \%)$ & $10(4 \%)$ \\
\hline Enterococcus spp. & $18(7 \%)$ & $4(12 \%)$ & $14(6 \%)$ \\
\hline Serratia spp. & $14(5 \%)$ & $2(6 \%)$ & $12(5 \%)$ \\
\hline Enterobacter spp. & $10(4 \%)$ & $1(3 \%)$ & $9(4 \%)$ \\
\hline Haemophilus spp. & $8(3 \%)$ & $2(6 \%)$ & $6(3 \%)$ \\
\hline Stenotrophomonas maltophilia & $7(3 \%)$ & $2(6 \%)$ & $5(2 \%)$ \\
\hline Proteus spp. & $4(1 \%)$ & $4(12 \%)$ & $0(0 \%)$ \\
\hline Morganella spp. & $3(11 \%)$ & $1(3 \%)$ & $2(1 \%)$ \\
\hline Moraxella spp. & $2(1 \%)$ & 0 & $2(1 \%)$ \\
\hline Acinetobacter spp. & $2(1 \%)$ & $1(3 \%)$ & $1(0 \%)$ \\
\hline Streptococcus pyogenes & $1(0.3 \%)$ & 0 & $1(0 \%)$ \\
\hline Candida albicans & $76(28 \%)$ & $12(35 \%)$ & $64(27 \%)$ \\
\hline Candida spp. (non albicans) & $21(8 \%)$ & $6(18 \%)$ & $15(6 \%)$ \\
\hline Aspergillus spp. & $6(2 \%)$ & $5(15 \%)$ & $1(0 \%)$ \\
\hline No organisms isolated & $74(27 \%)$ & $1(3 \%)$ & $73(30 \%)$ \\
\hline \multicolumn{4}{|c|}{$\begin{array}{l}\text { All clinically significant organisms from blood culture whilst in ICU (Number of individuals who ever had the } \\
\text { following organisms in any sample) }\end{array}$} \\
\hline Staphylococcus (non aureus) & $36(13 \%)$ & $7(21 \%)$ & $29(12 \%)$ \\
\hline Klebsiella spp. & $19(7 \%)$ & $4(12 \%)$ & $15(6 \%)$ \\
\hline Enterococcus spp & $8(3 \%)$ & $1(3 \%)$ & $7(3 \%)$ \\
\hline Escherichia coli & $5(2 \%)$ & $0(0 \%)$ & $5(2 \%)$ \\
\hline Pseudomonas spp & $4(1 \%)$ & $0(0 \%)$ & $4(2 \%)$ \\
\hline Staphylococcus aureus & $2(1 \%)$ & $1(3 \%)$ & $1(0 \%)$ \\
\hline Stenotrophomonas maltophilia & $2(1 \%)$ & $1(3 \%)$ & $1(0 \%)$ \\
\hline Citrobacter spp. & $1(0 \%)$ & $0(0 \%)$ & $1(0 \%)$ \\
\hline Enterobacter spp. & $1(0 \%)$ & $0(0 \%)$ & $1(0 \%)$ \\
\hline Proteus spp. & $1(0 \%)$ & $0(0 \%)$ & $1(0 \%)$ \\
\hline Candida (non albicans) & $2(1 \%)$ & $0(0 \%)$ & $2(1 \%)$ \\
\hline Candida albicans & $0(0 \%)$ & $0(0 \%)$ & $0(0 \%)$ \\
\hline
\end{tabular}


medRxiv preprint doi: https://doi.org/10.1101/2020.11.26.20229989; this version posted December 3, 2020. The copyright holder for this preprint (which was not certified by peer review) is the author/funder, who has granted medRxiv a license to display the preprint in

It is made available under a CC-BY-NC-ND 4.0 International license .

\begin{tabular}{|l|c|c|c|}
\hline Contaminants onlyc & $12(44 \%)$ & $4(12 \%)$ & $8(3 \%)$ \\
\hline No organisms isolated & $196(72 \%)$ & $16(47 \%)$ & $180(75 \%)$ \\
\hline Galactomannans (GAL) & & & \\
\hline Bronchoalveolar lavage (BAL) GALs & & & \\
\hline Number of tests / Patients tested & $76 / 51$ & $98 / 18$ & $1 / 1$ \\
\hline \multicolumn{1}{|c|}{ Positive tests / Patients positive } & $10 / 8$ & $9 / 7$ & $84 / 52$ \\
\hline Serum GALs & $119 / 74$ & $35 / 22$ & $4 / 4$ \\
\hline Number of tests / Patients tested & $7 / 7$ & $3 / 3$ & \\
\hline \multicolumn{1}{|c|}{ Positive tests / Patients positive } & & & 48 \\
\hline
\end{tabular}

a1 patient was SARS-CoV-2 RNA PCR negative but had clinical diganosis of COVID-19. ${ }^{\text {b1 patient in }}$ the metagenomics group and 48 patients from the non-metagenomics group had no respiratory specimens collected while on ITU. 'The significance of all blood-culture isolates was independently determined by the infectious diseases team as part of routine daily clinical consult service ward rounds on the ICUs 
medRxiv preprint doi: https://doi.org/10.1101/2020.11.26.20229989; this version posted December 3, 2020. The copyright holder for this preprint (which was not certified by peer review) is the author/funder, who has granted medRxiv a license to display the preprint in It is made available under perpetuity.

Table 2. Comparison of pathogens reported by routine culture with metagenomics sequencing in respiratory samples

\begin{tabular}{|c|c|c|c|c|}
\hline $\begin{array}{l}\text { Patient } \\
\text { ID }\end{array}$ & $\begin{array}{l}\text { Sample } \\
\text { ID }\end{array}$ & $\begin{array}{l}\text { ICU } \\
\text { ward }^{a}\end{array}$ & $\begin{array}{l}\text { Semi-quantitative } \\
\text { routine culture report }\end{array}$ & $\begin{array}{l}\text { Pathogens identified by } \\
\text { metagenomic } \\
\text { sequencing }\end{array}$ \\
\hline 26 & S35 & 6 & Acinetobacter spp. (L) & A. baumanni \\
\hline 100 & S39 & 5 & C.koseri $(\mathrm{H})$ & $\begin{array}{c}\text { C. koseri } \\
\text { K. pneumoniae }\end{array}$ \\
\hline 121 & S37 & 3 & $\begin{array}{l}\text { P.mirabilis (M) } \\
\text { M.morganii (M) }\end{array}$ & $\begin{array}{c}\text { P. mirabilis } \\
\text { M morgannii } \\
\text { K. pneumoniae }\end{array}$ \\
\hline 177 & S36 & 3 & S. aureus $(\mathrm{H})$ & S. aureus \\
\hline 196 & S42 & 3 & B. cenocepacia (L) & Burkholderia spp. \\
\hline 400 & S49 & 5 & K. pneumoniae (M) & K. pneumoniae \\
\hline 408 & S20 & 5 & S. aureus (M) & S. aureus \\
\hline \multirow[b]{2}{*}{441} & $\mathrm{~S} 21$ & 3 & E.cloacae (M) & E. cloacae \\
\hline & S51 & 5 & $\begin{array}{l}\text { S. aureus }(\mathrm{L}) \\
\text { C. koseri }(\mathrm{L})\end{array}$ & $\begin{array}{l}\text { S. aureus } \\
\text { C. koseri }\end{array}$ \\
\hline 550 & S10 & 2 & K. pneumoniae (M) & K. pneumoniae \\
\hline 563 & $\mathrm{~S} 28$ & 4 & Aspergillus (S) & $\begin{array}{l}\text { A. fumigatus } \\
\text { S. aureus }\end{array}$ \\
\hline 613 & S18 & 4 & Negative & Negative \\
\hline 618 & S45 & 5 & $\begin{array}{l}\text { C. striatum (M) } \\
\text { K. aerogenes (S) }\end{array}$ & C. striatum \\
\hline \multirow{3}{*}{677} & S52 & 7 & $K$. aerogenes $(\mathrm{L})$ & $\begin{array}{l}\text { K. aerogenes } \\
\text { C. striatum }\end{array}$ \\
\hline & S54 & 7 & C. striatum (M) & C. striatum \\
\hline & S63 & 4 & $\begin{array}{l}\text { K. pneumoniae }(\mathrm{M}) \\
\text { C. striatum }(\mathrm{M})\end{array}$ & $\begin{array}{l}\text { C. striatum } \\
\text { K. pneumoniae }\end{array}$ \\
\hline 727 & S53 & 7 & Negative & Negative \\
\hline \multirow[b]{2}{*}{740} & $\mathrm{~S} 30$ & 3 & Negative & Negative \\
\hline & S59 & 3 & $\begin{array}{l}\text { K. pneumoniae }(\mathrm{M}) \\
\text { C. striatum }(\mathrm{M})\end{array}$ & $\begin{array}{l}\text { K. pneumoniae } \\
\text { C. striatum }\end{array}$ \\
\hline 749 & S40 & 5 & Negative & Negative \\
\hline
\end{tabular}


medRxiv preprint doi: https://doi.org/10.1101/2020.11.26.20229989; this version posted December 3, 2020. The copyright holder for this preprint (which was not certified by peer review) is the author/funder, who has granted medRxiv a license to display the preprint in It is made available under a CC-BY-NC-ND 4.0 International license .

\begin{tabular}{|c|c|c|c|c|}
\hline & S62 & 3 & $\begin{array}{l}\text { K. aerogenes }(\mathrm{L}) \\
\text { C. striatum }(\mathrm{L})\end{array}$ & $\begin{array}{l}\text { K. aerogenes } \\
\text { C. striatum }\end{array}$ \\
\hline \multirow[b]{2}{*}{815} & S25 & 5 & Negative & Negative \\
\hline & S46 & 5 & C. koseri (M) & C. koseri \\
\hline 855 & S41 & 5 & Negative & S. aureus \\
\hline \multirow[b]{2}{*}{872} & S11 & 3 & K. pneumoniae $(\mathrm{H})$ & K. pneumoniae \\
\hline & S61 & 3 & $\begin{array}{c}\text { P. mirabilis }(\mathrm{H}) \\
\text { K. pneumoniae }(\mathrm{M})\end{array}$ & $\begin{array}{l}\text { P. mirabilis } \\
\text { K. pneumoniae } \\
\text { C. koseri }\end{array}$ \\
\hline 1033 & S8 & 1 & A. fumigatus (S) & $\begin{array}{l}\text { A. fumigatus } \\
\text { K. oxytoca }\end{array}$ \\
\hline 1036 & S5 & 1 & Negative & Negative \\
\hline 1054 & S31 & 3 & K. pneumoniae $(\mathrm{L})$ & K. pneumoniae \\
\hline \multirow{2}{*}{1065} & S16 & 1 & Negative & S. aureus \\
\hline & S19 & 1 & Negative & Negative \\
\hline 1069 & S17 & 1 & $P$. aeruginosa $(\mathrm{M})$ & $P$. aeruginosa \\
\hline 1082 & S14 & 1 & Negative & Negative \\
\hline 1092 & S27 & 1 & Negative & Negative \\
\hline 1262 & S29 & 1 & Negative & Negative \\
\hline 1292 & S44 & 1 & $\begin{array}{l}\text { S. marcescens }(\mathrm{L}) \\
\text { K. aerogenes }(\mathrm{S})\end{array}$ & $\begin{array}{l}\text { S. marcescens } \\
\text { C. freundii }\end{array}$ \\
\hline 1346 & S56 & 1 & $\begin{array}{l}\text { A. fumigatus }(\mathrm{S}) \\
\text { P. mirabilis }(\mathrm{L})\end{array}$ & $\begin{array}{l}\text { A. fumigatus } \\
\text { P. mirabilis }\end{array}$ \\
\hline 1440 & S33 & 1 & Negative & Negative \\
\hline \multirow{2}{*}{1457} & S64 & 1 & Negative & Negative \\
\hline & S65 & 1 & Negative & Negative \\
\hline
\end{tabular}


medRxiv preprint doi: https://doi.org/10.1101/2020.11.26.20229989; this version posted December 3, 2020. The copyright holder for this preprint (which was not certified by peer review) is the author/funder, who has granted medRxiv a license to display the preprint in It is made available under a CC-BY-NC-ND 4.0 International license .

\begin{tabular}{|c|c|c|c|c|}
\hline 1503 & S1 & 1 & K. aerogenes (L) & K. aerogenes \\
\hline 1512 & $\mathrm{~S} 34$ & 1 & K. pneumoniae (L) & K. pneumoniae \\
\hline 1538 & $\mathrm{~S} 55$ & 3 & Negative & A. fumigatus \\
\hline
\end{tabular}

aThe seven dedicated adult COVID-19 ITUs comprise existing adult ITUs (1,3 and 4), a pre-purposed paediatric ITU (5), two post-operative recovery units (2 and 6) and a specialist chronic respiratory unit

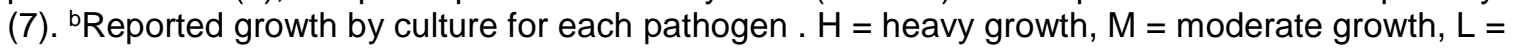
light growth

Criteria for reporting organisms was $\geq 1 \%$ of microbial classified reads and with a centrifuge score $\geq 2504$ 
medRxiv preprint doi: https://doi.org/10.1101/2020.11.26.20229989; this version posted December 3, 2020. The copyright holder for this preprint (which was not certified by peer review) is the author/funder, who has granted medRxiv a license to display the preprint in It is made available under a perpetuity.

Table 3. Comparison of CMg identified acquired genotypic resistance with phenotypic culture results and the impact on guideline-recommended antibiotic treatment

\begin{tabular}{|c|c|c|c|c|c|c|}
\hline $\begin{array}{l}\text { Sample } \\
\text { ID }\end{array}$ & $\begin{array}{l}\text { Bacteria } \\
\text { reported by } \\
\text { culture and } \\
\text { metagenomics }\end{array}$ & $\begin{array}{l}\text { Culture-reported } \\
\text { acquired } \\
\text { resistance }\end{array}$ & $\begin{array}{l}\text { CMg predicted } \\
\text { acquired } \\
\text { resistance }\end{array}$ & $\begin{array}{l}\text { Relevant } \\
\text { genes } \\
\text { identified }\end{array}$ & $\begin{array}{c}\text { Genotype/ } \\
\text { Phenotype } \\
\text { match? }\end{array}$ & $\begin{array}{l}\mathrm{CMg} \text { based } \\
\text { treatment } \\
\text { recommendation }\end{array}$ \\
\hline S1 & K. aerogenes & No & - & - & $\mathrm{Y}$ & Meropenem \\
\hline S10 & K. pneumoniae & No & - & - & $\mathrm{Y}$ & Co-amoxiclav \\
\hline $\mathrm{S} 11$ & K. pneumoniae & No & - & - & $\mathrm{Y}$ & Co-amoxiclav \\
\hline S16 & K. pneumoniae & No & - & - & $\mathrm{Y}$ & Co-amoxiclav \\
\hline S20 & S. aureus & Erythromycin & Erythromycin & erm & $\begin{array}{l}Y \\
Y\end{array}$ & Co-amoxiclav \\
\hline S21 & E. cloacae & No & No & - & $\mathrm{Y}$ & Meropenem \\
\hline S31 & K. pneumoniae & $\begin{array}{c}\text { ESBL } \\
\text { Co-trimoxazole }\end{array}$ & $\begin{array}{c}\text { ESBL } \\
\text { Co-trimoxazole }\end{array}$ & $\begin{array}{c}\text { blateм, blas } \\
\text { Hv blactx-м, } \\
\text { sul }\end{array}$ & $\begin{array}{l}Y \\
Y\end{array}$ & Meropenem \\
\hline S34 & K. pneumoniae & No & ESBL & $\begin{array}{l}\text { blatem } \\
\text { blasHv }\end{array}$ & $\mathrm{N}$ & Meropenem ${ }^{\mathrm{b}}$ \\
\hline S35 & A. baumannii & ESBL & - & & $\mathrm{N}$ & Meropenem \\
\hline S36 & S. aureus & $\begin{array}{l}\text { Erythromycin } \\
\text { Trimethoprim }\end{array}$ & $\begin{array}{l}\text { Erythromycin } \\
\text { Trimethoprim }\end{array}$ & $\begin{array}{l}\text { erm } \\
\text { dfrG }\end{array}$ & $Y$ & Co-amoxiclav \\
\hline \multirow[b]{2}{*}{ S37 } & P. mirabilis & No & $\begin{array}{l}\text { Amoxicillin } \\
\text { Trimethoprim }\end{array}$ & $\begin{array}{c}\text { blaoxa } \\
\text { dfrA }\end{array}$ & $\begin{array}{l}\mathrm{N} \\
\mathrm{N}\end{array}$ & \multirow[b]{2}{*}{ Meropenem } \\
\hline & M. morganni & $\begin{array}{l}\text { Co-trimoxazole } \\
\text { Fosfomycin } \\
\text { Nitrofurantoin }\end{array}$ & $\begin{array}{c}\text { Co-trimoxazole } \\
- \\
-\end{array}$ & $d f r A$ & $\begin{array}{l}\mathrm{Y} \\
\mathrm{N} \\
\mathrm{N}\end{array}$ & \\
\hline S39 & C. koseri & Amoxicillin & Amoxicillin & blacко & $\mathrm{Y}$ & Co-amoxiclav \\
\hline $\mathrm{S} 44$ & S. marcescens & No & - & - & $\mathrm{Y}$ & Meropenem \\
\hline S49 & K. pneumoniae & ESBL & ESBL & blatem & $\mathrm{Y}$ & Meropenem \\
\hline \multirow{2}{*}{ S51 } & S. aureus & Erythromycin & Erythromycin & erm & $Y$ & \multirow{2}{*}{ Co-amoxiclav } \\
\hline & C. koseri & Amoxicillin & Amoxicillin & blacko & $\mathrm{Y}$ & \\
\hline S52 & K. aerogenes & Gentamicin & - & - & $N$ & Meropenem \\
\hline S56 & P. mirabilis & $\begin{array}{c}\text { Amoxicillin } \\
\text { Co-trimoxazole }\end{array}$ & $\begin{array}{c}\text { Amoxicillin } \\
-\end{array}$ & $\begin{array}{c}\text { blaтем } \\
-\end{array}$ & $\begin{array}{l}\mathrm{Y} \\
\mathrm{N}\end{array}$ & Co-amoxiclav \\
\hline S59 & K. pneumoniae & $\begin{array}{c}\text { ESBL } \\
\text { Co-trimoxazole }\end{array}$ & $\begin{array}{c}\text { ESBL } \\
\text { Co-trimoxazole }\end{array}$ & $\begin{array}{l}\text { blatem, } \\
\text { blasHv, } \\
\text { sul }\end{array}$ & $\begin{array}{l}Y \\
Y\end{array}$ & Meropenem \\
\hline \multirow{2}{*}{ S61 } & P. mirabilis & No & - & - & $\mathrm{Y}$ & \multirow{2}{*}{ Co-amoxiclav } \\
\hline & K. pneumoniae & No & - & - & $Y$ & \\
\hline $\mathrm{S} 62$ & K. aerogenes & ESBL & - & - & $\mathrm{N}$ & Meropenem \\
\hline S63 & K. pneumoniae & ESBL & ESBL & blasHv & $Y$ & Meropenem \\
\hline
\end{tabular}


Table 4. Mycological tests and clinical characteristics of patients with at least one result suggestive of invasive pulmonary Aspergillosis.

\begin{tabular}{|c|c|c|c|c|c|c|c|c|c|c|}
\hline \multirow{2}{*}{ Patient } & \multicolumn{4}{|c|}{ A. fumigatus detection in respiratory samples } & \multicolumn{2}{|c|}{$\begin{array}{l}\text { Galactomannan } \\
\text { (Positive/Tested) }\end{array}$} & \multicolumn{3}{|c|}{ AspICU - Putative Criteria (24) } & \multirow{2}{*}{ ECMO } \\
\hline & $\begin{array}{l}\text { Sample } \\
\text { Number }\end{array}$ & CMg & qPCR (Cq) & $\begin{array}{c}\text { Culture } \\
\text { (Positive/Tested) }\end{array}$ & $\begin{array}{l}\text { BAL } \\
>1.0\end{array}$ & $\underset{>0.5}{\text { Serum }}$ & Radiology & Clinical & Host & \\
\hline \multirow{2}{*}{563} & S28 & Positive & 31 & Positive & & & \multirow{2}{*}{ Yes } & \multirow{2}{*}{ Yes } & \multirow{2}{*}{ Yes - steroid } & \multirow{2}{*}{ No } \\
\hline & Other & ND & ND & $3 / 6$ & $0 / 1$ & $0 / 0$ & & & & \\
\hline \multirow{2}{*}{613} & S18 & Negative & $>40$ & Negative & & & \multirow{2}{*}{ Yes } & \multirow{2}{*}{ Yes } & \multirow{2}{*}{ No } & \multirow{2}{*}{ No } \\
\hline & Other & ND & ND & $2 / 2$ & $1 / 1$ & $0 / 0$ & & & & \\
\hline \multirow{4}{*}{677} & S63 & Negative & $>40$ & Negative & & & \multirow{4}{*}{ Yes } & \multirow{4}{*}{ Yes } & \multirow{4}{*}{ Yes - steroid } & \multirow{4}{*}{ No } \\
\hline & S54 & Negative & $>40$ & Negative & & & & & & \\
\hline & S52 & Negative & $>40$ & Negative & & & & & & \\
\hline & Other & ND & ND & $0 / 8$ & $2 / 2$ & $0 / 5$ & & & & \\
\hline \multirow{3}{*}{740} & S59 & Negative & $>40$ & Negative & & & \multirow{3}{*}{ Yes } & \multirow{3}{*}{ Yes } & \multirow{3}{*}{$\begin{array}{c}\text { Yes - } \\
\text { Leukaemia on } \\
\text { chemotherapy }\end{array}$} & \multirow{3}{*}{ No } \\
\hline & S30 & Negative & $>40$ & Negative & & & & & & \\
\hline & Other & ND & ND & $0 / 16$ & $1 / 4$ & $1 / 2$ & & & & \\
\hline \multirow{2}{*}{1033} & S8 & Positive & 33 & Positive & & & \multirow{2}{*}{ Yes } & \multirow{2}{*}{ Yes } & \multirow{2}{*}{ Yes - steroid } & \multirow{2}{*}{ Yes } \\
\hline & Other & ND & ND & $0 / 0$ & $1 / 1$ & $1 / 1$ & & & & \\
\hline \multirow{2}{*}{1346} & S56 & Positive & 32 & Positive & & & \multirow{2}{*}{ Yes } & \multirow{2}{*}{ Yes } & \multirow{2}{*}{$\begin{array}{l}\text { Yes - steroid, } \\
\text { anakinra }\end{array}$} & \multirow{2}{*}{ Yes } \\
\hline & Other & ND & ND & $0 / 3$ & $1 / 1$ & $0 / 2$ & & & & \\
\hline 1440 & S33 & Negative & $>40$ & Negative & & & Yes & Yes & & Yes \\
\hline
\end{tabular}




\begin{tabular}{|c|c|c|c|c|c|c|c|c|c|c|}
\hline & Other & ND & ND & $0 / 4$ & $1 / 2$ & $0 / 1$ & & & $\begin{array}{l}\text { Yes - steroid, } \\
\text { anakinra }\end{array}$ & \\
\hline \multirow{3}{*}{1457} & S65 & Negative & $>40$ & Negative & & & \multirow{3}{*}{ Yes } & \multirow{3}{*}{ Yes } & \multirow{3}{*}{ Yes - steroid } & \multirow{3}{*}{ Yes } \\
\hline & S64 & Negative & $>40$ & Negative & & & & & & \\
\hline & Other & ND & ND & $0 / 9$ & $2 / 2$ & $0 / 2$ & & & & \\
\hline \multirow{2}{*}{1538} & S55 & Positive & 31 & Negative & & & \multirow{2}{*}{ Yes } & \multirow{2}{*}{ Yes } & \multirow{2}{*}{$\begin{array}{c}\text { Yes - } \\
\text { Lymphoma on } \\
\text { chemotherapy }\end{array}$} & \multirow{2}{*}{ No } \\
\hline & Other & ND & ND & $4 / 5$ & $0 / 0$ & $1 / 1$ & & & & \\
\hline
\end{tabular}

$\mathrm{ND}=$ Not done 
medRxiv preprint doi: https://doi.org/10.1101/2020.11.26.20229989; this version posted December 3, 2020. The copyright holder for this preprint (which was not certified by peer review) is the author/funder, who has granted medRxiv a license to display the preprint in

It is made available under a CC-BY-NC-ND 4.0 International license .

\section{References}

1. Edgeworth J. Antibiotic resistance in the ICU. In: Webb A, Gattinoni, Luciano, editor. Oxford textbook of critical care: Oxford University Press; 2016.

2. Torres A, Niederman MS, Chastre J, Ewig S, Fernandez-Vandellos P, Hanberger $\mathrm{H}$, et al. International ERS/ESICM/ESCMID/ALAT guidelines for the management of hospital-acquired pneumonia and ventilator-associated pneumonia. European Respiratory Journal. 2017;50(3):1700582.

3. Cookson WOCM, Cox MJ, Moffatt MF. New opportunities for managing acute and chronic lung infections. Nature Reviews Microbiology. 2017;16:111.

4. Garcin F, Leone M, Antonini F, Charvet A, Albanèse J, Martin C. Non-adherence to guidelines: an avoidable cause of failure of empirical antimicrobial therapy in the presence of difficult-to-treat bacteria. Intensive Care Medicine. 2010;36(1):75-82.

5. Veerdonk FLvd, Kolwijck E, Lestrade PPA, Hodiamont CJ, Rijnders BJA, Paassen Jv, et al. Influenza-associated Aspergillosis in Critically III Patients. American Journal of Respiratory and Critical Care Medicine. 2017;196(4):524-7.

6. Verweij PE, Rijnders BJA, Brüggemann RJM, Azoulay E, Bassetti M, Blot S, et al. Review of influenza-associated pulmonary aspergillosis in ICU patients and proposal for a case definition: an expert opinion. Intensive Care Medicine. 2020;46(8):1524-35.

7. Sanguinetti M, Posteraro B, Beigelman-Aubry C, Lamoth F, Dunet V, Slavin M, et al. Diagnosis and treatment of invasive fungal infections: looking ahead. Journal of Antimicrobial Chemotherapy. 2019;74(Supplement_2):ii27-ii37.

8. Ullmann AJ, Aguado JM, Arikan-Akdagli S, Denning DW, Groll AH, Lagrou K, et al. Diagnosis and management of Aspergillus diseases: executive summary of the 2017 ESCMID-ECMM-ERS guideline. Clinical microbiology and infection : the official publication of the European Society of Clinical Microbiology and Infectious Diseases. 2018;24 Suppl 1:e1-e38.

9. Cox MJ, Loman N, Bogaert D, O'grady J. Co-infections: potentially lethal and unexplored in COVID-19. The Lancet Microbe. 2020;1(1):e11.

10. Sharifipour E, Shams S, Esmkhani M, Khodadadi J, Fotouhi-Ardakani R, Koohpaei A, et al. Evaluation of bacterial co-infections of the respiratory tract in COVID-19 patients admitted to ICU. BMC Infectious Diseases. 2020;20(1):646.

11. Vaillancourt M, Jorth P. The Unrecognized Threat of Secondary Bacterial Infections with COVID-19. mBio. 2020;11(4):e01806-20.

12. Beer KD, Jackson BR, Chiller T, Verweij PE, Van de Veerdonk FL, Wauters J. Does Pulmonary Aspergillosis Complicate Coronavirus Disease 2019? Crit Care Explor. 2020;2(9):e0211-e.

13. Zhou F, Yu T, Du R, Fan G, Liu Y, Liu Z, et al. Clinical course and risk factors for mortality of adult inpatients with COVID-19 in Wuhan, China: a retrospective cohort study. Lancet (London, England). 2020;395(10229):1054-62.

14. Waldeck F, Boroli F, Suh N, Wendel Garcia PD, Flury D, Notter J, et al. Influenza-associated aspergillosis in critically-ill patients-a retrospective bicentric cohort study. Eur J Clin Microbiol Infect Dis. 2020;39(10):1915-23.

15. Thompson lii GR, Cornely OA, Pappas PG, Patterson TF, Hoenigl M, Jenks JD, et al. Invasive Aspergillosis as an Under-recognized Superinfection in COVID-19. Open Forum Infectious Diseases. 2020;7(7).

16. Group TWREAfC-TW. Association Between Administration of Systemic Corticosteroids and Mortality Among Critically III Patients With COVID-19: A Meta-analysis. JAMA. 2020;324(13):1330-41. 17. Group TRC. Dexamethasone in Hospitalized Patients with Covid-19 - Preliminary Report. New England Journal of Medicine. 2020.

18. Charalampous T, Kay GL, OeGrady J. Applying clinical metagenomics for the detection and characterisation of respiratory infections. The Lung Microbiome (ERS Monograph) Sheffield, European Respiratory Society. 2019:35-49. 
medRxiv preprint doi: https://doi.org/10.1101/2020.11.26.20229989; this version posted December 3, 2020. The copyright holder for this preprint (which was not certified by peer review) is the author/funder, who has granted medRxiv a license to display the preprint in

It is made available under a CC-BY-NC-ND 4.0 International license.

19. Chiu CY, Miller SA. Clinical metagenomics. Nature Reviews Genetics. 2019.

20. Charalampous T, Kay GL, Richardson H, Aydin A, Baldan R, Jeanes C, et al. Nanopore metagenomics enables rapid clinical diagnosis of bacterial lower respiratory infection. Nature Biotechnology. 2019;37(7):783-92.

21. Thoendel MJ, Jeraldo PR, Greenwood-Quaintance KE, Yao JZ, Chia N, Hanssen AD, et al. Identification of Prosthetic Joint Infection Pathogens Using a Shotgun Metagenomics Approach. Clinical infectious diseases : an official publication of the Infectious Diseases Society of America. 2018;67(9):1333-8.

22. Street TL, Barker L, Sanderson ND, Kavanagh J, Hoosdally S, Cole K, et al. Optimizing DNA extraction methods for Nanopore sequencing of \&lt;em\&gt;Neisseria gonorrhoeae\&lt;/em\&gt; direct from urine samples. Journal of Clinical Microbiology. 2019:JCM.01822-19.

23. Gu W, Deng X, Lee M, Sucu YD, Arevalo S, Stryke D, et al. Rapid pathogen detection by metagenomic next-generation sequencing of infected body fluids. Nature Medicine. 2020.

24. Blot SI, Taccone FS, Van den Abeele AM, Bulpa P, Meersseman W, Brusselaers N, et al. A clinical algorithm to diagnose invasive pulmonary aspergillosis in critically ill patients. American journal of respiratory and critical care medicine. 2012;186(1):56-64.

25. Schauwvlieghe AF, Rijnders BJ, Philips N, Verwijs R, Vanderbeke L, Van Tienen C, et al. Invasive aspergillosis in patients admitted to the intensive care unit with severe influenza: a retrospective cohort study. The Lancet Respiratory Medicine. 2018;6(10):782-92.

26. Verweij PE, Gangneux J-P, Bassetti M, Brüggemann RJ, Cornely OA, Koehler P, et al. Diagnosing COVID-19-associated pulmonary aspergillosis. The Lancet Microbe. 2020;1(2):e53-e5.

27. Fukumoto $\mathrm{H}$, Sato $\mathrm{Y}$, Hasegawa $\mathrm{H}$, Saeki H, Katano $\mathrm{H}$. Development of a new real-time PCR system for simultaneous detection of bacteria and fungi in pathological samples. 2015;8(11):15479-

88.

28. Edgeworth JD, Batra R, Wulff J, Harrison D. Reductions in Methicillin-resistant Staphylococcus aureus, Clostridium difficile Infection and Intensive Care Unit-Acquired Bloodstream Infection Across the United Kingdom Following Implementation of a National Infection Control Campaign. Clinical Infectious Diseases. 2020;70(12):2530-40.

29. Edgeworth JD, Chis Ster I, Wyncoll D, Shankar-Hari M, McKenzie CA. Long-term adherence to a 5 day antibiotic course guideline for treatment of intensive care unit (ICU)-associated Gramnegative infections. The Journal of antimicrobial chemotherapy. 2014;69(6):1688-94.

30. Greninger AL, Naccache SN, Federman S, Yu G, Mbala P, Bres V, et al. Rapid metagenomic identification of viral pathogens in clinical samples by real-time nanopore sequencing analysis. Genome Medicine. 2015;7(1):99.

31. Peddu V, Shean RC, Xie H, Shrestha L, Perchetti GA, Minot SS, et al. Metagenomic Analysis Reveals Clinical SARS-CoV-2 Infection and Bacterial or Viral Superinfection and Colonization. Clinical chemistry. 2020;66(7):966-72.

32. Langelier C, Zinter MS, Kalantar K, Yanik GA, Christenson S, O'Donovan B, et al. Metagenomic Sequencing Detects Respiratory Pathogens in Hematopoietic Cellular Transplant Patients. American Journal of Respiratory and Critical Care Medicine. 2018;197(4):524-8.

33. Wang J, Han Y, Feng J. Metagenomic next-generation sequencing for mixed pulmonary infection diagnosis. BMC Pulmonary Medicine. 2019;19(1):252.

34. Zinter MS, Dvorak CC, Mayday MY, Iwanaga K, Ly NP, McGarry ME, et al. Pulmonary Metagenomic Sequencing Suggests Missed Infections in Immunocompromised Children. Clinical Infectious Diseases. 2018;68(11):1847-55.

35. He B-C, Liu L-L, Chen B-L, Zhang F, Su X. The application of next-generation sequencing in diagnosing invasive pulmonary aspergillosis: three case reports. Am J Transl Res. 2019;11(4):2532-9.

36. Ruppé E, Cherkaoui A, Lazarevic V, Emonet S, Schrenzel J. Establishing Genotype-toPhenotype Relationships in Bacteria Causing Hospital-Acquired Pneumonia: A Prelude to the Application of Clinical Metagenomics. Antibiotics (Basel). 2017;6(4):30. 
medRxiv preprint doi: https://doi.org/10.1101/2020.11.26.20229989; this version posted December 3, 2020. The copyright holder for this preprint (which was not certified by peer review) is the author/funder, who has granted medRxiv a license to display the preprint in

It is made available under a CC-BY-NC-ND 4.0 International license.

37. Břinda K, Callendrello A, Ma KC, MacFadden DR, Charalampous T, Lee RS, et al. Rapid inference of antibiotic resistance and susceptibility by genomic neighbour typing. Nature Microbiology. 2020;5(3):455-64.

38. Greninger AL, Zerr DM, Qin X, Adler AL, Sampoleo R, Kuypers JM, et al. Rapid Metagenomic Next-Generation Sequencing during an Investigation of Hospital-Acquired Human Parainfluenza Virus 3 Infections. J Clin Microbiol. 2017;55(1):177-82.

39. Kafetzopoulou LE, Pullan ST, Lemey P, Suchard MA, Ehichioya DU, Pahlmann M, et al. Metagenomic sequencing at the epicenter of the Nigeria 2018 Lassa fever outbreak. Science. 2019;363(6422):74.

40. Langelier C, Kalantar KL, Moazed F, Wilson MR, Crawford ED, Deiss T, et al. Integrating host response and unbiased microbe detection for lower respiratory tract infection diagnosis in critically ill adults. Proceedings of the National Academy of Sciences. 2018;115(52):E12353.

41. Yang L, Haidar G, Zia H, Nettles R, Qin S, Wang X, et al. Metagenomic identification of severe pneumonia pathogens in mechanically-ventilated patients: a feasibility and clinical validity study. Respiratory Research. 2019;20(1):265.

42. Harris PNA, Tambyah PA, Lye DC, Mo Y, Lee TH, Yilmaz M, et al. Effect of PiperacillinTazobactam vs Meropenem on 30-Day Mortality for Patients With E coli or Klebsiella pneumoniae Bloodstream Infection and Ceftriaxone Resistance: A Randomized Clinical Trial. Jama. 2018;320(10):984-94.

43. Pilmis B, Jullien V, Tabah A, Zahar J-R, Brun-Buisson C. Piperacillin-tazobactam as alternative to carbapenems for ICU patients. Annals of Intensive Care. 2017;7(1):113.

44. Zander J, Döbbeler G, Nagel D, Maier B, Scharf C, Huseyn-Zada M, et al. Piperacillin concentration in relation to therapeutic range in critically ill patients--a prospective observational study. Crit Care. 2016;20:79-.

45. Antinori S, Rech R, Galimberti L, Castelli A, Angeli E, Fossali T, et al. Invasive pulmonary aspergillosis complicating SARS-CoV-2 pneumonia: A diagnostic challenge. Travel Med Infect Dis. 2020:101752-.

46. Van de Veerdonk FL, Wauters, Joost and Verweij, Paul E. Invasive Aspergillus Tracheobronchitis Emerging as a Highly Lethal Complication of Severe Influenza. American journal of respiratory and critical care medicine. 2020;202(5):646-8.

47. Mehta P, McAuley DF, Brown M, Sanchez E, Tattersall RS, Manson JJ, et al. COVID-19: consider cytokine storm syndromes and immunosuppression. Lancet (London, England). 2020;395(10229):1033.

48. Heard KL, Hughes S, Mughal N, Moore LS. COVID-19 and fungal superinfection. The Lancet Microbe. 2020;1(3):e107.

49. Calabrese F, Pezzuto F, Fortarezza F, Hofman P, Kern I, Panizo A, et al. Pulmonary pathology and COVID-19: lessons from autopsy. The experience of European Pulmonary Pathologists. Virchows Arch. 2020;477(3):359-72.

50. Carsana L, Sonzogni A, Nasr A, Rossi RS, Pellegrinelli A, Zerbi P, et al. Pulmonary postmortem findings in a series of COVID-19 cases from northern Italy: a two-centre descriptive study. The Lancet Infectious Diseases. 2020.

51. Santana MF, Pivoto G, Alexandre MAA, Baía-da-Silva DC, Borba MGdS, Val FA, et al. Confirmed Invasive Pulmonary Aspergillosis and COVID-19: the value of postmortem findings to support antemortem management. Revista da Sociedade Brasileira de Medicina Tropical. 2020;53. 52. Donnelly JP, Chen SC, Kauffman CA, Steinbach WJ, Baddley JW, Verweij PE, et al. Revision and update of the consensus definitions of invasive fungal disease from the European Organization for Research and Treatment of Cancer and the Mycoses Study Group Education and Research Consortium. Clinical Infectious Diseases. 2020;71(6):1367-76.

53. Dhesi Z, Enne VI, Brealey D, Livermore DM, High J, Russell C, et al. Organisms causing secondary pneumonias in COVID-19 patients at 5 UK ICUs as detected with the FilmArray test. medRxiv. 2020:2020.06.22.20131573. 
medRxiv preprint doi: https://doi.org/10.1101/2020.11.26.20229989; this version posted December 3, 2020. The copyright holder for this preprint (which was not certified by peer review) is the author/funder, who has granted medRxiv a license to display the preprint in

It is made available under a CC-BY-NC-ND 4.0 International license.

54. Strydom KA, Chen L, Kock MM, Stoltz AC, Peirano G, Nobrega DB, et al. Klebsiella pneumoniae ST307 with OXA-181: threat of a high-risk clone and promiscuous plasmid in a resourceconstrained healthcare setting. Journal of Antimicrobial Chemotherapy. 2020;75(4):896-902.

55. Peirano G, Chen L, Kreiswirth BN, Pitout JDD. Emerging Antimicrobial-Resistant High-Risk \&lt;span class=\&quot;named-content genus-species\&quot; id=\&quot;named-content1\&quot;\&gt;Klebsiella pneumoniae\&lt;/span\&gt; Clones ST307 and ST147. Antimicrobial Agents and Chemotherapy. 2020;64(10):e01148-20.

56. Verroken A, Bauraing C, Deplano A, Bogaerts P, Huang D, Wauters G, et al. Epidemiological investigation of a nosocomial outbreak of multidrug-resistant Corynebacterium striatum at one Belgian university hospital. Clinical Microbiology and Infection. 2014;20(1):44-50.

57. Brandenburg AH, van Belkum A, van Pelt C, Bruining HA, Mouton JW, Verbrugh HA. Patientto-patient spread of a single strain of Corynebacterium striatum causing infections in a surgical intensive care unit. Journal of clinical microbiology. 1996;34(9):2089-94.

58. Iaria C, Stassi G, Costa G, Biondo C, Gerace E, Noto A, et al. Outbreak of multi-resistant Corynebacterium striatum infection in an Italian general intensive care unit. The Journal of hospital infection. 2007;67:102-4.

59. Vlek AL, Cooper BS, Kypraios T, Cox A, Edgeworth JD, Auguet OT. Clustering of antimicrobial resistance outbreaks across bacterial species in the intensive care unit. Clinical infectious diseases : an official publication of the Infectious Diseases Society of America. 2013;57(1):65-76.

60. Standards Unit MS, Public Health England. UK Standards for Microbiology Investigations. Investigation of bronchoalveolar lavage, sputum and associated specimens. 2018. Contract No.: 3.4. 61. Kim D, Song L, Breitwieser FP, Salzberg SL. Centrifuge: rapid and sensitive classification of metagenomic sequences. Genome research. 2016;26(12):1721-9.

62. Kos VN, Déraspe M, McLaughlin RE, Whiteaker JD, Roy PH, Alm RA, et al. The Resistome of \&lt;span class=\&quot;named-content genus-species\&quot; id=\&quot;named-content-

1\&quot;\&gt;Pseudomonas aeruginosa\&lt;/span\&gt; in Relationship to Phenotypic Susceptibility. Antimicrobial Agents and Chemotherapy. 2015;59(1):427.

63. O'Leary NA, Wright MW, Brister JR, Ciufo S, Haddad D, McVeigh R, et al. Reference sequence (RefSeq) database at NCBI: current status, taxonomic expansion, and functional annotation. Nucleic acids research. 2016;44(D1):D733-45.

64. Li H. Minimap2: pairwise alignment for nucleotide sequences. Bioinformatics. 2018;34(18):3094-100.

65. Li H. A statistical framework for SNP calling, mutation discovery, association mapping and population genetical parameter estimation from sequencing data. Bioinformatics. 2011;27(21):298793.

66. Page AJ, Taylor B, Delaney AJ, Soares J, Seemann T, Keane JA, et al. SNP-sites: rapid efficient extraction of SNPs from multi-FASTA alignments. Microbial genomics. 2016;2(4):e000056. 


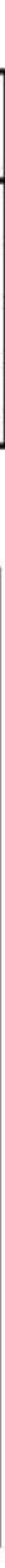

